\title{
Influence of anticoagulants on the measurement of S100B protein in blood
}

\author{
Adriano B.L. Tort ${ }^{\mathrm{a}}$, Marcelo O. Dietrich ${ }^{\mathrm{a}}$, Carlos A. Gonçalves ${ }^{\mathrm{a}}$, Diogo O. Souza ${ }^{\mathrm{a}}$, \\ Luis V.C. Portela ${ }^{\mathrm{a}, \mathrm{b}, *}$ \\ ${ }^{a}$ Departamento de Bioquímica, ICBS, UFRGS, Brazil \\ ${ }^{\mathrm{b}}$ Faculdade de Biociências, PUCRS, Brazil
}

Received 18 March 2003; received in revised form 17 June 2003; accepted 23 June 2003

\begin{abstract}
Objective: Evaluate anticoagulants influence on blood S100B levels.

Design and methods: Blood from 18 healthy adult subjects were collected using: no anticoagulants; EDTA; heparin; and citrate. S100B levels were determined using LIA-mat assay.

Results: Heparin and citrate increased S100B levels $(p<0.001)$, whereas EDTA had no effect $(p=0.24)$. Heparin samples were highly $\left(\mathrm{r}^{2}=0.97, p<0.001\right)$, citrate samples were moderately $\left(\mathrm{r}^{2}=0.49, p<0.001\right)$, and EDTA samples were not $\left(\mathrm{r}^{2}=0.22, p=0.059\right)$ correlated with serum samples.

Conclusion: When anticoagulant is required, heparin should be the primary choice.

(C) 2003 The Canadian Society of Clinical Chemists. All rights reserved.

Keywords: S100B; Blood; anticoagulants; Immunoluminometric assay

\section{Introduction}

S100 is a multigenic family of calcium binding proteins of the EF-hand type, implicated in intracellular and extracellular modulatory activities. One of the 19 members of S100 family is the S100B protein, which is physiologically produced and released primarily by astrocytes in the central nervous system (CNS), where it exerts neurotrophic and gliotrophic actions [1]. Depending on the extracellular or intracellular functional activity, S100B exerts its modulatory effects on targets proteins in calcium dependent and, in some instances, calcium independent manner [1].

In addition to the basic studies concerning physiologic functions of S100B [1], a number of clinical approaches suggests that the measurement of S100B level in blood and cerebrospinal fluid (CSF) is a potential tool to evaluate neural injury, involving reactive gliosis, astrocytic death, and/or blood-brain barrier dysfunction. Accordingly, increased CSF and/or blood levels have been reported in

* Corresponding author. Fax: +00-55-51-3316-5540.

E-mail address: roska@ufrgs.br (L.V.C. Portela).

several acute and chronic brain injuries, as traumatic brain injury [2], stroke [3], schizophrenia [4], HTLV-I associated myelopathy [5]. Despite the findings in pathologic events, we also found significant variations in blood levels with age, from neonates to adult healthy subjects [6].

Considering the increasing potential application of S100B measurement on clinical investigation, as well as its relevance to basic research, accurate evaluation of conditions that affect its measurement in biologic fluids is extremely relevant. Two sensitive analytical methods have been frequently employed in studies involving measurement of S100B protein: an immunofluorimetric assay (IFMA), validated by Missler et al. 1995 [7], and a commercial immunoluminometric assay, LIA ${ }^{\circledR}$-mat BYK- Sangtec ${ }^{\circledR} 100$ (LIA-mat), Dietzembach, Germany. Although the LIA-mat probably have been the most used to measure S100B protein levels in the current years, various analytical matter related to exogenous or endogenous compounds which could affect the accuracy of the immunoluminometric assay still need better characterization. In the present work, we evaluated whether different anticoagulants normally used in clinical and laboratory practice affect blood S100B measurement, by using LIA-mat kit.
\end{abstract}


Table 1

Demographic data and S100B values in serum and plasma

\begin{tabular}{|c|c|c|c|c|c|c|}
\hline \multirow[t]{2}{*}{ Subject } & \multirow[t]{2}{*}{ Gender } & \multirow[t]{2}{*}{ Age (years) } & \multicolumn{4}{|c|}{ S100B serum levels (ng/L) } \\
\hline & & & $\begin{array}{l}\text { Without } \\
\text { anticoagulant }\end{array}$ & EDTA $(\%)$ & Heparin $(\%)$ & Citrate $(\%)$ \\
\hline 1 & M & 42 & 11.00 & $37.00(336)$ & $22.00(200)$ & $8.00(73)$ \\
\hline 2 & $\mathrm{~F}$ & 21 & 31.00 & $93.00(29)$ & $50.00(161)$ & $60.00(194)$ \\
\hline 3 & $\mathrm{~F}$ & 24 & 130.00 & $65.00(50)$ & $153.00(118)$ & $103.00(79)$ \\
\hline 4 & $\mathrm{~F}$ & 24 & 67.00 & $93.00(139)$ & $71.00(106)$ & $115.00(172.00)$ \\
\hline 5 & M & 23 & 30.00 & $34.00(113)$ & $56.00(187)$ & $47.00(157)$ \\
\hline 6 & $\mathrm{~F}$ & 23 & 65.00 & $300.00(462)$ & $102.00(157)$ & $193.00(297)$ \\
\hline 7 & M & 21 & 82.00 & $251.00(306)$ & $104.00(127)$ & $119.00(145)$ \\
\hline 8 & M & 22 & 115.00 & $206.00(179)$ & $149.00(130)$ & $240.00(209)$ \\
\hline 9 & M & 21 & 45.00 & $13.00(29)$ & $54.00(120)$ & $12.00(27)$ \\
\hline 10 & $\mathrm{~F}$ & 24 & 220.00 & $153.00(70)$ & $242.00(110)$ & $256.00(116)$ \\
\hline 11 & M & 27 & 51.00 & $20.00(39)$ & $86.00(169)$ & $92.00(180)$ \\
\hline 12 & $\mathrm{~F}$ & 28 & 100.00 & $108.00(108)$ & $125.00(125)$ & $179.00(179)$ \\
\hline 13 & M & 27 & 16.00 & $8.00(50)$ & 23.00 (144) & $71.00(444)$ \\
\hline 14 & M & 31 & 108.00 & $177.00(164)$ & $125.00(116)$ & $117.00(108)$ \\
\hline 15 & M & 20 & 95.00 & $64.00(67)$ & $116.00(122)$ & $111.00(117)$ \\
\hline 16 & F & 32 & 61.00 & $52.00(85)$ & $75.00(123)$ & $47.00(77)$ \\
\hline 17 & M & 21 & 17.00 & $55.00(324)$ & $40.00(235)$ & $26.00(153)$ \\
\hline 18 & $\mathrm{~F}$ & 24 & 39.00 & Missed* & $57.00(146)$ & $206.00(528)$ \\
\hline Means $\pm \mathrm{SD}$ & & $25.29 \pm 5.40$ & $71.27 \pm 51.79$ & $96.76 \pm 89.65$ & $91.66 \pm 54.94$ & $111.22 \pm 76.16$ \\
\hline
\end{tabular}

\section{Subjects and methods}

Blood samples were drawn by a single venipuncture in the antecubital vein using Vacutainer ${ }^{\circledR}$ system (BectonDickinson, Plymouth, UK). In a period of two hours, we collected sequentially blood from 18 healthy adult subjects (mean age: $25.3 \pm 5.4, \mathrm{M} / \mathrm{F} 10 / 8$ ) using four different tubes: (i) without anticoagulants; (ii) EDTA; (iii) sodium heparin; and (iv) sodium citrate. The plasma or serum was obtained by centrifugation at $3000 \mathrm{~g}$ for $5 \mathrm{~min}$ and, soon afterwards, was frozen at $-70^{\circ} \mathrm{C}$ during $24 \mathrm{~h}$, when was performed the measurement of serum S100B levels. An informed consent was obtained from all subjects. This study was approved by local ethics committee.

S100B levels were determined using the monoclonal immunoluminometric assay (LIA-mat ${ }^{\circledR}$ Sangtec $^{\circledR}$ 100; BYK-Sangtec Medical). Briefly, blood samples and calibrators $(100 \mu \mathrm{L})$ were diluted with $100 \mu \mathrm{L}$ of bovine serum albumin solution in test tubes provided with the assay, which were already coated with anti-S100B antibody. After incubating for $1 \mathrm{~h}$, the tubes were washed, and $200 \mu \mathrm{L}$ of a $\mathrm{S} 100 \mathrm{~B}$ antibody labeled with isoluminol as a tracer was added. After an additional $2 \mathrm{~h}$ incubation, the tubes were washed to remove the unlabelled antibody and the emitted luminescence resulted from the oxidation of isoluminol by hydrogen peroxide was measured in a Lumat LB9507 luminometer (EG\&G Berthold). S100B concentrations were derived by comparison with the calibration curve. The S100B calibration curve was linear up to $20 \mu \mathrm{g} / \mathrm{L}$, and the CVs for duplicates across the entire concentration range for the calibrators and samples were $<5 \%$. The detection limit of the assay is $0.02 \mu \mathrm{g} / \mathrm{L}$, as provided by the supplier of the kit.

Statistical analyses were performed using Student's $t$-test for comparisons between the plasma S100B levels obtained with each anticoagulant and serum S100B levels. Pearson's correlation was assessed between the plasma S100B levels obtained with different anticoagulants and the serum levels. A $p<0.05$ was considered statistically significant.

\section{Results}

Table 1 shows demographic data and S100B levels in serum and plasma samples. Heparin and citrate plasma samples presented statistically significant increase in the levels of the protein when compared with serum levels $(p<$ 0.001 ), whereas EDTA plasma sample presented no difference $(p=0.24)$. Plasma S100B levels, when collected with heparin, were highly correlated with serum levels $\left(r^{2}=\right.$ $0.97, p<0.001$ ), whereas plasma obtained with citrate was moderately correlated $\left(\mathrm{r}^{2}=0.49, p<0.001\right)$, and with EDTA presented no correlation $\left(\mathrm{r}^{2}=0.22, p=0.059\right)$, as shown in Figure 1.

\section{Discussion}

In the last years, studies aimed to achieve clinical applications for potential biochemical markers of CNS injury have gained larger interest, and, among the brain markers, S100B accounts with a significant number of publications in this theme [3,5,6]. Besides CNS injury, S100B blood levels 

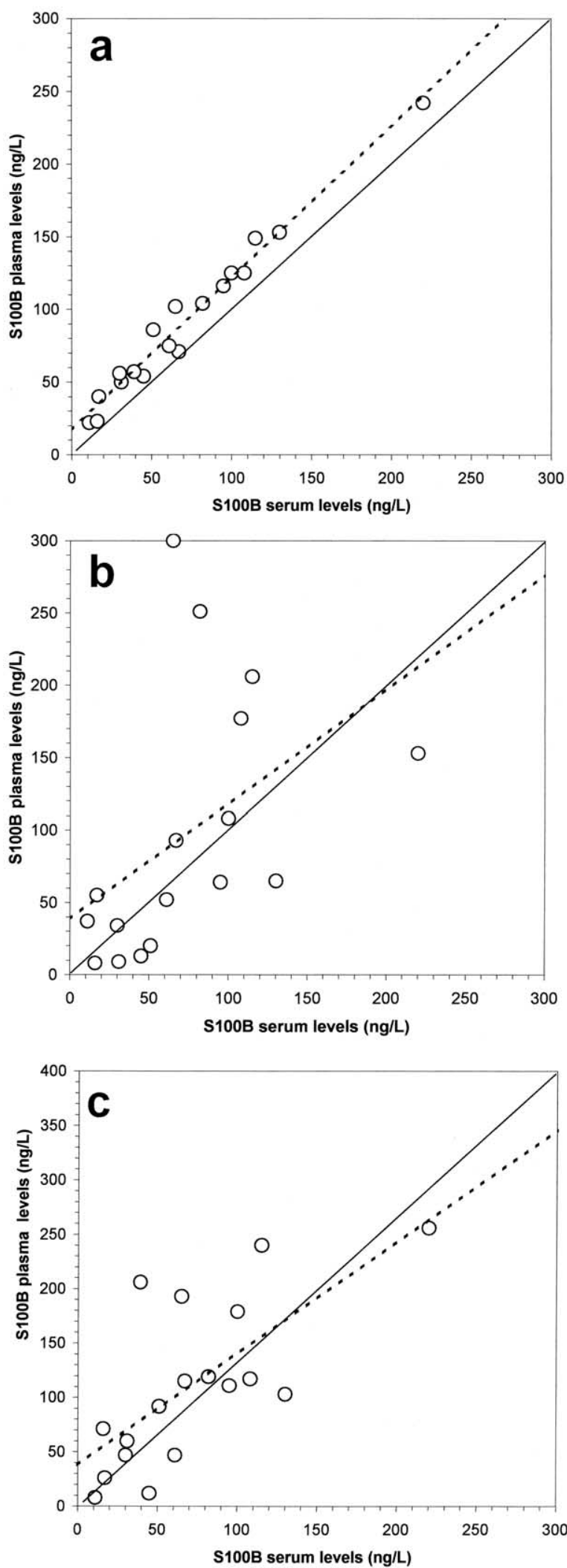

Fig. 1. The scatter shows the relation between the S100B levels of serum $(x$-axis) and plasma ( $y$-axis) obtained with different anticoagulants. In (a) heparin $\left(r^{2}=0.97\right)$, in (b) EDTA $\left(r^{2}=0.22\right)$, and in (c) citrate $\left(r^{2}=0.49\right)$ were plotted. Values above or below the continuous line represent increase or decrease, respectively, in relation to serum. The dashed line was obtained using a linear regression. were also reported to be elevated in some nonnervous pathologic conditions, specially melanoma [8]. Therefore, we believe that the assessment of the effects of potential interferents on the measurement of S100B by LIA-mat kit is a worthwhile effort. This safety caution can contribute to avoid falsely positive or negative results, as well as discrepancies among results from different laboratories.

Previous works demonstrated some methodological aspects involving S100B measurement using LIA-mat kit. In a comparative study, Missler et al. 1995 [7] reported that the pattern of sensitivity, cross-reactivity and specificity of analytical methods LIA-mat and IFMA were very similar. The presence of hemolysis up to $800 \mathrm{mg} / \mathrm{L}$ of hemoglobin neither modified plasma S100B concentration, nor interfered with LIA-mat assay [9]. Concerning the influence of anticoagulants, in one previous study with five patients, the presence of heparin did not affect the measurement of S100B [10]. To our knowledge, the others clinically used anticoagulants were not previously evaluated.

In our study, we compared the S100B levels of the same subjects collected with or without anticoagulants used in clinical routine (EDTA, heparin and citrate). The present data showed a close correlation between S100B in serum (which is the sample recomended by the manufacturer) and plasma obtained with heparin. However heparin constantly appeared to increase the immunoreactivity for S100B in about $45 \%$, which should be considered in clinical studies. Importantly, heparin is normally employed as anticoagulant in patients undergoing cardiac surgery with extracorporeal circulation in studies where the quantification of S100B by LIA-mat has been used to evaluate brain injury [10].

On the other hand, the presence of the others anticoagulants in blood samples interfered chaotically on the S100B measurement by LIA-mat kit. This effect could be atributed to the mechanism underlying the anticoagulant effects of EDTA and citrate, which are calcium chelators, whereas heparin action is independent of calcium.

It has been shown that some antibodies to calciumbinding proteins preferentially recognize particular calciuminduced protein conformational states [11], and the immunoreactivity of antibodies for S100B protein depends on its calcium-binding status [10]. Here, we observed a strong interference on the immunoreactivity when calcium chelators were present, which suggests that the monoclonal antibodies for S100B from BYK-Sangtec ${ }^{\circledR}$ are affected by calcium presence. Moreover, this interference impairs to correlate S100B levels in plasma obtained by EDTA or citrate with serum levels.

\section{Conclusion}

In conclusion, the present work does not support the use of EDTA and citrate for sampling blood to measure S100B by LIA-mat kit. If the use of anticoagulant is required, the 
results pointed to heparin as the primary choice, however it should be used in both control and patient subjects.

\section{Acknowledgments}

This work was supported by CAPES, CNPq and PRONEX/Finep \#41960904.

\section{References}

[1] Donato R. S100: a multigenic family of calcium-modulated proteins of the EF-hand type with intracellular, and extracellular functional roles. Int J Biochem Cell Biol 2001;33:637-68.

[2] Ingebrigtsen T, Waterloo K, Jacobsen EA, Langbakk B, Romner B. Traumatic brain damage in minor head injury: relation of serum S-100 protein measurements to magnetic resonance imaging and neurobehavioral outcome. Neurosurgery 1999;45:468-75.

[3] Wunderlich MT, Ebert AD, Kratz T, Goertler M, Jost S, Herrmann M. Early neurobehavioral outcome after stroke is related to release of neurobiochemical markers of brain damage. Stroke 1999;30:1190-5.

[4] Lara DR, Gama CS, Belmonte-de-Abreu P, Portela LV, Gonçalves $\mathrm{CA}$, Fonseca $\mathrm{M}$, et al. Increased serum $\mathrm{S} 100 \mathrm{~B}$ protein in schizophrenia: a study in medication-free patients. J Psychiatr Res 2001;35: $11-4$.
[5] Walz R, Portela LV, Tort AB, Neto EC, Fernandes LN, Gonçalves CA, et al. Serum S100B levels in patients with HTLV-I-associated myelopathy/tropical spastic paraparesis. Neurology 2000;54:2021-2.

[6] Portela LV, Tort AB, Schaf DV, Ribeiro L, Nora DB, Walz R, et al. The serum S100B concentration is age dependent. Clin Chem 2002; 48:950-2.

[7] Missler U, Wiesmann M, Ehlermann P, Tronnier M, Notzold A, Steinmeier E, et al. Validation and comparison of two solid-phase immunoassays for the quantification of S-100B in human blood. Clin Chem 2000;46:993-6.

[8] Hamberg AP, Korse CM, Bonfrer JM, de Gast GC. Serum S100B is suitable for prediction and monitoring of response to chemoimmunotherapy in metastatic malignant melanoma. Melanoma Res 2003;13: 45-9.

[9] Beaudeux JL, Leger P, Dequen L, Gandjbakhch I, Coriat P, Foglietti MJ. Influence of hemolysis on the measurement of S-100beta protein and neuron-specific enolase plasma concentrations during coronary artery bypass grafting. Clin Chem 2000;46:989-90.

[10] Gao F, Harris DN, Sapsed-Byrne S, Sharp S. Neurone-specific enolase and Sangtec 100 assays during cardiac surgery: Part I-The effects of heparin, protamine and propofol. Perfusion 1997;12:163-5.

[11] Goncalves CA, Gottfried C, Kommers T, Rodnight R. Calciummodulated proteins change their immunoreactivity in the presence of $\mathrm{Ca} 2+$ : a study of antibody recognition in a dot immunoassay for calmodulin, calcineurin (beta-subunit), and S100B. Anal Biochem 1997;253:127-30 